\title{
Alarm Assembly Device
}

National Cancer Institute

\section{Source}

National Cancer Institute. Alarm Assembly Device. NCI Thesaurus. Code C49812.

A composite part of an alarm or a larger device that includes an alarm. 